\title{
Playing Aggression: the social construction of the 'sassy girl' in a peer culture play routine
}

\author{
SAMARA MADRID \\ University of Wyoming, Laramie, USA
}

\begin{abstract}
The ethnographic analysis presented here examines a play routine that centered on two four-year-old female children constructing and being 'sassy girls'. Data was gathered over the course of six months in one preschool classroom by acting as a participant observer, videotaping, audiotaping, and conducting formal and informal interviews with the teacher. The analysis consisted of taking a broad contextualized ethnographic view of the children's play themes in the daily life of the classroom, followed by a focused eight-week observation of the reoccurring sassy girl play routine. Patterns and themes that emerged from all data sources were triangulated and interpreted through feminist and peer culture theoretical lenses. Results revealed that the girls used this play to create gendered affiliations, perform 'meanness', explore power, and resist the school culture rules about aggression in the classroom.
\end{abstract}

\begin{abstract}
How are girls constructed into categories such as successful girls, mean girls, bad girls, and violent girls? How are major concerns over girls' aggression and meanness related to current gender anxieties over middle class 'girl power' and girls' success? How are girls pathologized into such oppositional categories as the successful but mean 'Supergirls' and the counterpart to this type, the failed, deviant, abject, violent non-feminine girls who must be transformed? These are some of the core dilemmas foisted on girls within contemporary girlhood in the West. (Ringrose \& Walkerdine, 2008, p. 6)
\end{abstract}

Ringrose and Walkerdine raise questions about contemporary girlhood and the construction of categories, such as mean girl, bad girl and successful girl, and the relation between those categories and gender anxieties over girl power and girl success. They make visible the dilemmas and subject positions young girls face not only with their 'gendered identities', but also their gendered 'emotional' identities in contemporary girlhood. Gonick (2004, p. 395) writes, 'The vulnerable girl has recently been replaced by the 'mean girl' in public consciousness'. If this claim is true, how has the mean girl been appropriated to wield power and serve friendship dynamics in the lives of preschool girls in Western society? How has the social practice of meanness impacted young girls peer culture play? This article explores how two four-year-old girls socially constructed a peer culture play routine (i.e. sassy girl) to create gendered affiliations, perform 'meanness', explore power and resist the school culture rules about aggression in the classroom. More specifically, the sassy girl embodied the performance of the 'mean girl' and provided a play venue where the girls could explore direct and indirect aggression through exclusion, teasing, taunting, tricking, hitting and name calling.

\section{Gendered Play and Emotion}

One way that young children produce and negotiate their gendered and emotional identities is through play (Davies, 1989; Fernie et al, 1993; Thorne, 1993; Gilbert, 1994; Walkerdine, 1997; 
Yelland \& Grieshaber, 1998; MacNaughton, 2000; Shields, 2002; Blaise, 2005; Lipkin, 2009; Madrid \& Kantor, 2009; Wohlwend, 2009; Madrid, 2011). McNaughton (2000) suggests that gender is collectivity produced and negotiated as children play the dominant images, texts, and storylines about being male and female. For example, in play, children take-up the various positions associated with being a nurturing mother, a loving princess, a brave prince, a heroic superhero, or a scary monster. Through these roles, however, children are not simply pretending to be a prince, princess, hero, or mother; they are also learning how to perform the emotional themes specific to these gendered play roles:

For example, the narrative themes and multiple characters that are the features of doll play afford similar situations to think about and practice emotion openly as a dimension of relationships and social exchange. Further, the conditions within the group are such that different expectations are established regarding which emotions ought to occur and how they should be reacted to.

(Shields, 2002, p. 105)

In the act of creating play narratives and characters that are gender-specific and gender-exclusive, children define and delimit the types of emotional responses and behaviors that can be enacted within such play roles. For example, the emotions enacted as a domestically-oriented mother are very different from the emotions enacted as a protective father. Shields adds to our understanding by also noting that doing emotion is doing gender, "What my account adds to this mix is the idea that education of the emotions includes how emotion expresses personhood, especially gender. Emotion education includes not only "because you are a boy, feel/show X, but also show feel/show X in order to become a boy"' (2002, p. 91). Thus, in girls' doll play, princess play, or teacher play, girls are not simply learning how to do femininity as a mother, princess, or teacher, but also how to do the gender-specific emotions associated with these subject positions (Davies $\&$ Harré, 1990). Emotional identities from this standpoint are not viewed as stable internal constructs, but rather are fluid, shifting, and dynamic constructs embedded with social and cultural assumptions about how, when, where and with whom males and females can and should display emotions as defined by the gendered roles they are playing and performing (Burr, 2003).

In the neo-liberal post-feminist era, however, females are now expected, or rather assumed, to display characteristics and emotions that are both feminine and masculine (Brooks, 1997; Genz, 2009) complicating the discourse of emotions embodied in gendered play. For instance, in Girl Culture, Ringrose and Walkerdine (2008) discuss the notions of two young females, Colby and Esther, about being a girl in the twenty-first century:

The (girls) say they want to be both feminine and assertive, like their mothers. Colby makes the point at lunch that she would rather be considered too assertive and less conventionally feminine than to be totally passive and a bystander in my life. (p. 7)

Young girls' emotional identities are no longer informed just by a mother who displays traditional nurturing characteristics or by the helpless princess who needs to be rescued by the prince. Young girls are now observing and playing the twenty-first century female, opening up a space to accept, reject, take-up, and transform the traditional and domestic play roles. For example, in a recent observation I overheard a girl in the house area tell her peer 'I am getting ready to see my baby's daddy'. Girls can now be found playing super girls who rescue the prince, powerful married career women, and single mothers with ex-husbands, boyfriends, or a 'baby's daddy'. Girls are engaging in play themes related to the independent, powerful, sexually liberated and successful female, who does not privilege the traditional domestic sphere of the past.

With the changes in the roles available for women, there has also arisen an interest in and concerns about contemporary girlhood and the type of 'girl' our society is creating both emotionally and socially. Increasing attention has been given specifically to the adolescent mean girl or super girl who uses indirect aggression such as exclusion, teasing, gossip, and bullying to control and manipulate peers. The position, however, is problematic as it has been used in an attempt to make claims that girls are just as aggressive as boys (when indirect aggression is considered), which has pathologized feminine aggression based on a 'feminine culture of meanness' (Ringrose, 2006, p. 414). More importantly for early childhood educators, the pathology of girl's indirect aggression is beginning to circulate and have effects on how young girls are perceived and understood. 
The effect is that not only are differences between girls and the particular circumstance of their lives glossed over, but girls layered and complex expressions of identity, power, and resistance are collapsed into certain ubiquitous meanings of girlhood with an ever expanding reach. For example, in a recent informal conversation, I heard the 'mean girl' phenomena, originally used with reference to pre-teen and teenage girls, as an explanation for the classroom interactions of four-year-old girls in a California preschool. Once these meanings enter our 'common sense' lexicon their pervasiveness results in a narrowing of vision and imagination for the multitude of ways in which girls self-expression might be read and engaged. (Gonick, 2004, p. 397)

Given this push-down about mean girls in public discourse, it is vital that early childhood researchers and teachers critically question the taken-for-granted assumptions about what constitutes meanness and examine how dominant and pervasive gendered discourses continue to regulate and inform what emotional themes girls 'should' and 'should not' play and express in the everyday life of the classroom. It should also be examined in cultural and social context, as related to the concerns and desires of four-year-old girls in Western society.

This article offers a critical look at the productive power and multiple readings of girl's aggression and meanness and offers an opportunity for early educators to interrogate how young girls use this position for their own peer culture purposes, i.e. to gain power, share control with peers, and construct gendered identities. It also opens up a much needed discussion about the possible meanings of girl's aggression in the preschool classroom.

\section{Conceptual Framework}

Using post-structural feminist thought (Walkerdine, 1997; Weedon, 1997; Butler, 1999; Davies, 2000), and peer culture perspectives of children's play and emotional lives (Fernie et al, 1993; Kantor \& Fernie, 2003; Corsaro, 2005; Madrid \& Kantor, 2009; Madrid, 2011), the purpose of this analysis is to explore how girls constructed a play theme centered on the emotional theme of aggression and being 'sassy'. From these theoretical perspectives, gender and emotion are socially constructed phenomena that people do rather than have, and are located in language, discourse, ideology, and bound by power relations, which in turn informs how young girls take-up and perform masculinity and femininity.

Femininity is not viewed an inherent characteristic or property of an individual, as the categories of 'boy 'or 'girl' and 'masculine' and 'feminine' are continually being reinscribed in moment-to-moment actions and reactions (Butler, 1999). Femininity is shifting, plural, contested, regulated, performed and situated in history, culture, race, and social class (Davies, 2000, p. 15). Feminist post-structural accounts offer an analytical tool to understand how young girls appropriate and use language and discursive positionings in multiple ways to accomplish multiple goals without relying on static and singular conceptions of gender or emotion. Moreover, the subject or girl is in continual flux and negotiation as 'the individual is always the site of conflicting forms of subjectivity', leaving room for a critical examination about how young girls resist or create alternative ways of constituting girlhood and the emotional themes associated with feminine subjectivities (Weedon, 1997, p. 32).

Similarly, a peer culture perspective positions children as dynamic and active subjects in negotiating their own unique culture within an adult centered world (Corsaro, 2003, 2005; Kantor \& Fernie, 2003; Fernie et al, 2011). Children's peer culture is defined as 'a stable set of activities or routines, artifacts, values, and concerns that children produce and share in interaction with peers' (Corsaro, 2005, p.95). Adult culture is not simply transmitted to children, but instead is appropriated and 'interpretively reproduced' by children for their own purposes of gaining control and sharing power with their peers. Children have agency in taking-up the world around them, playfully transforming and resisting adult conceptions and categories to address their own agendas in the social life of the classroom (Kyratzis, 2004). The first question below guided data collection for the larger ethnographic study from which this data emerged. The second question guided an eight-week targeted observation and this particular data analysis.

1. What were the play themes girls used in their peer culture play over time and across situations in the daily life of the preschool classroom? 
2. How did girls construct and use a play theme centered on being 'sassy girls' over time and across situations in the daily life of the classroom?

\section{Methodology}

The data presented here comes from a larger six-month ethnographic study of one preschool classroom. Data from multiple sources were gathered as a way to triangulate the data and build trustworthiness. Data was gathered by a participant observer (Spradley, 1980) who took field notes, videotaped interactions, audiotaped conversations, conducted formal interviews and informal interviews with teachers, and then revisited all these data. Videotaping occurred approximately two times per week for several hours in the morning during the children's free play. The camera was positioned either in a stationary spot near the researcher, or carried along if the children moved around the classroom. Children would also use the video camera sometimes to videotape their own play as the camera became part of the classroom routine. Informal interviews occurred on a weekly basis with the teacher. Data were continually interpreted and reinterpreted through a recursive cycle of question-asking and answering (Hatch, 2002).

\section{Research Context}

The study took place in a university-affiliated Early Education and Care Center located in the Northwest of the United States of America (USA). Study participants included fifteen children (eight girls and seven boys) from one preschool classroom, one lead teacher, and three teacher aides. Most of the children, their parents and teachers were educated, white, middle-class Americans. Given that the classroom was affiliated with the university, pre-service early childhood and child development students were often in and out of the classrooms for observation and/or practicum, making the center a very busy and active space. The philosophy of the center was grounded in a child-centered, play-based approach and in the notion that the teacher should always be engaged with children through play and/or project learning. There were three preschool classrooms, two toddler classrooms, and one infant classroom located in the center.

The portion of the data selected and analyzed in this article is taken from an eight-week period in which the researcher strategically selected two preschool females, Kiara and Liza, as target children for a purposeful theoretical sampling of a salient play theme (Corsaro, 1985). The choice to focus on a particular group of female children was based on the reoccurring pattern of the sassy girl play routine specific to these children that was documented by the teacher and researcher over time and across situations in the classroom. Both girls were dominant children in the classroom and generally played the sassy girl routine with the same three females (Mia, Jackie, and Kim). These core groups of females were the oldest girls in the classroom, had all been in the classroom the year prior to the study, and tended not to include the younger female children in their play. Their play was typically gendered-segregated and often centered on play themes such as shopping, princess, Barbie, birthday party, house, and school.

\section{Target Children}

Liza: Liza was a four-year-old, white, middle class girl who had been in the preschool classroom for one year prior to the study. She was a leader in the classroom who also tended to be verbally and physically aggressive with her peers. For example, she often called other children stupid or would hit them if they did not share a toy. She was not rejected by her peers because of her aggression, but it did cause concern for teachers and parents. Liza would often engage in family and princess socio-dramatic play themes with female peers. She was an only child and lived with both parents.

Kiara: Kiara was a four-year-old, white, middle class girl who had been in the preschool classroom for one year prior to the study. She was a leader among her peers and often used relational aggression to control her play and friendship space. She was interested in Barbie and Disney princess play. The teacher noted that she had been trying to 'purchase' toys from other children. For example, once when a child did not want to share his play dough, she offered him five dollars. 
When asked what she wanted to be when she grew up she stated, 'a winning fashion designer'. Kiara had a younger and an older sibling and lived with both parents.

\section{Lead Teacher}

The lead teacher, Emily, was a white 27-year-old female with an undergraduate degree in child development. She had been teaching at the center for three years and was highly respected and valued by the curriculum coordinator and director of the program as a teacher that understood the importance of play and the rights of the child. She took an active role as co-researcher, often documenting children's play themes and emotions. She viewed the child as the 'co-director' of the classroom and let children take the lead in creating learning opportunities and projects based on their interests. Her teaching philosophy was consistent with the play-based philosophy of the center and a negotiated curriculum design. The unspoken classroom agenda was to build children's social and emotional skills through play and child-to-child problem-solving and conflict resolution. Her classroom structure and focus on social and emotional development provided a rich and fertile setting to study children's play ethnographically.

\section{Data Analysis}

Using Spradley's (1980) ethnographic analysis, a wide lens was taken to explore and document the play themes that were occurring in the daily life of the classroom. After play events occurred, they were recorded and noted in the field notes, which were reviewed on the day of data collection, and revisited again when related events occurred. Next, the analytical lens was narrowed to document and videotape one salient, recurring play theme (i.e. sassy girl), noting how, when, where, and with whom it occurred and the emotional themes associated with the play. Illustrative videotaped events that occurred during the focused observation were then transcribed from the larger corpus.

The last stage of data analysis consisted of systemically examining the transcripts at a micro level (Bloome et al, 2005) to interpret the girl's actions and reactions using a feminist post-structural lens of children's play (Davies, 1989; Walkerdine, 1997) and Butler's (1999) notion of performativity. This allowed for a close examination and the 'unpacking' of how language, discourse and power relations were circulating and shifting as the girls embodied, produced and negotiated the sassy girl in the peer and school culture. The micro level analysis also focused on interpreting and questioning how the girl's actions contested, accepted and created various subject positions associated with girlhood and femininity, and how these gendered meanings varied for the girls as the play theme evolved in the classroom context with their peers and adults. All transcribed events were situated in the broader classroom life through examination of field notes taken prior to and after events transpired in the classroom, which were indexed (Emerson et al, 1995). Such events were also discussed with teachers formally and informally during and after the time they occurred. The findings were also shared with the teacher to confirm and/or disconfirm the accuracy of interpretations.

\section{Role of Researcher}

The ethnographic procedures of Corsaro $(1985,2005)$ were employed to gain access into the children's peer culture and reduce my adult power, which eventually allowed children to behave naturally in my presence. Similar to the 'least-adult' role described by Mandell (1988), I did not lead or censor any of the children's play activities and joined in their free play (inside and outside) when invited. I was also very careful in choosing to participate during times and in areas that were semichild-structured and entirely child-structured as these were spaces where children and their peers engaged 'in the process of constructing rules, routines and ritualistic interactional procedures' (Mandell, 1988, p. 438); in other words, in contexts where children were creating the structure. I also did not discipline or make judgments about the children's behaviors during these interactions as that would have changed the nature and purpose of their play in such child-dominated spaces.

During the first month of the study, however, the teachers and girls often seemed confused about my role in the classroom and had to be reminded that I did not take on teacher behavior. 
With time, patience, and consistency, my role became well defined as a person who was there to play with the target children, rather than as a teacher or teacher's aide who would monitor, lead and intervene in play. This shift became apparent as the girls would engage in behaviors in front of me that would not have been allowed by adults in the classroom (e.g. sneaking toys, talking about the teacher, name calling, teasing, and physical aggression). The girls also began to treat me in a non-teacher manner during our play. For example, I was playing with Liza, holding a pen in my hand when she sternly informed me, 'Only teachers are allowed to have those'; grabbing the pen out of my hand and handing it over to a teacher. On the same day, I told Liza I wanted to go outside and play. Liza replied, 'You have to wait for a teacher', which was followed up by asking if I had a cubby (i.e. a space where children keep personal items in the classroom). It is important to note that while Liza and Kiara did not position me as a teacher who censored and regulated their actions, they also did not allow me into their sassy girl clique, but rather treated me as a target of their sassiness. Other female children, however, would protect me and invite me into the play theme providing me access into the play space. Given this, my researcher role was complicated and at times somewhat 'uncomfortable' as children were aggressive both to me and their peers as they took on the sassy girl role.

All of the data presented here and the interactions between me and the children took place as I participated in the 'least adult' role in the classroom and was documented through videotaped and/or field notes during our play. Children were not formally interviewed about the play theme at any time, but rather were asked questions about their play in-situ at opportune moments. The teacher, however, would often query the children outside of the actual play event (without my promoting), which she would report back to me during our interviews. Playing and talking with the children was used to 'member check' and triangulate their perspective and experiences in their naturally occurring moment-to-moment interactions. This was followed with formal and informal conversations with the teacher and the teacher aides to gain their perspective about the play and how it transformed when I was not in the classroom.

\section{Findings and Interpretation}

\section{The Construction of the 'Sassy Girl'}

The sassy girl theme appeared at the start of the school year in August. It was a play routine that had not been part of the classroom routine during the year before and occurred mainly during children's free play (although there were instances of the sassy girl play theme during lunch and circle time). Many of the children had been away for the summer. With their return came the emergence of the sassy girl, which at first occurred as Kiara and a core group of females (Mia and Jackie) approached boys with their hands on their hips and teased and taunted them. Over time, and through multiple interactions playing with the girls, I found that being a sassy girl was a feminine play role that only girls could assume and embodied a tough, feminine 'don't mess with me' attitude as indicated by the highly feminized gesture of placing the hands on the hips and their choice to describe themselves as 'sassy girls' versus 'sassy boy' or just 'sassy'. Sassy girl was not a play theme sparked by classroom discussions or the teachers' comments about Kiara or any of the other girls being sassy. It was Kiara who created the storyline and discursively positioned herself and her female friends as 'sassy girls', which they all quickly accepted.

As noted in the methodology, the teacher became an active participant as a co-researcher, noting the play themes that were occurring when I was not present in the classroom. It was from the teacher that I first learned about the sassy girl play theme:

Teacher Emily: The other thing I was going to tell you about was, yesterday, Kiara totally started this thing where she was like leading around like Mia and Jackie, probably all the girls, and she was leading them around going 'We're sassy girls. We're sassy girls'. And like going up to the boys and like putting their hand on their hips and like 'We're sassy girls'. And like it's this whole thing that just like totally just happened, and like at lunch today, like I don't know how it happened, but it was like Kiara and Mia were just like 'Yeah and we're sassy girls' and both Calvin and I were just like 'No, no, we're not doing that, guys. Sorry'. [Laugh] And so then they sort of whispered to each other 'Okay, well we're just going to be sassy, but they won't know'. 
When the play theme emerged the teacher and teacher's aide rejected the girls attempt to take-up and create this subject position within their play. This is illustrated when the teacher states, 'No, we're not doing that, guys'. The adult disapproval, however, did not keep Kiara and Liza from engaging in the theme, but rather pushed the theme underground as indicated by the girls' whisper (directly after the teacher's comment) 'We're just going to be sassy, but they won't know'. Subsequently, the lead teacher decided not to censor the play theme. Instead, she noted and closely observed the sassy girl play theme in an effort to understand the children's peer culture interest.

While Kiara was the initial instigator of the sassy girl play, Liza quickly joined in and each girl took a turn in creating, maintaining, and taking-up the sassy girl position over the course of eight weeks. As such, the play role was not an individual act of 'sassiness', but a collective play routine used by several females. Categorizing themselves as 'sassy girls' signaled they were a certain type of 'girl' and demonstrated affiliation to an exclusive girl group within this preschool classroom, regulating which girls in the classroom could (re)produce this gendered identity (Butler, 1999). For example, the sassy girl play theme could not be accessed by just anyone in the classroom, as only a core group of females were 'The Sassy Girls' (i.e. Kiara, Mia, Jackie, Kim and Liza), which in turn created group identity and cohesion among these five girls. Younger girls and boys who were not part of the sassy girl group would attempt to gain access into the play by stating they were 'sassy' or illustrating they had 'sassy girl' material items (i.e. accessories, clothes, toys, and books). The girls would quickly reject these attempts by other children by simply ignoring them or stating that they did not have sassy girl items.

During an informal classroom discussion, the teacher suggested that Kiara might have picked up the term 'sassy girl' from the media, although there was never any reference to specific sassy characters. Kiara and Liza also did not reference popular culture items when they played sassy girl, although they did label specific items such a jewelry, hair clips, toys, clothes, and ways of walking and talking as 'sassy'. When the teacher asked directly about how sassy girls related to the media and popular culture items, Kiara said there were not any sassy girls on television. After further prompting by the teacher, she did say there was a 'sassy musketeer' in one of her videos who makes messes and makes other people clean them up. She stated they were not playing her because 'she is purple' (i.e. wore a purple dress). The sassy musketeer is found in the movie Barbie and the Three Musketeers (2009) which centers on several females pursuing their dream of becoming a musketeer, a role only available to males. The storyline is embedded with post-feminist conceptions about girl power and femininity. While Kiara stated that they were not the purple sassy musketeer, she does reveal knowledge about a sassy girl as someone whose behavior is not compliant or pro-social (i.e. the sassy girl makes others clean up her mess).

\section{Sassy Girl: performing meanness}

As noted in the previous sections, the girls actively created and maintained the sassy girl play routine in the daily life of their peer culture and used it to build affiliation and limit access into their gendered peer group. The gendered performance was reinscribed through the moment-to-moment actions and reactions associated with doing the 'sassy girl', allowing the girls to explore and construct the different types of activities and subjectivities as females who were not pro-social (Butler, 1999; Aapola et al, 2005). For example, a few days after Kiara initiated the sassy girl play theme, the following event occurred between a teacher's aide and Kiara:

Kiara is playing in the dark room with some other children, playing 'sassy girls'. The teacher goes over and asks, 'What are you girls doing?'. Kiara replies, 'We're playing sassy girls!'. The teacher says, 'What are sassy girls?'. Kiara replies, 'They're mean. You can play with us, but you have to be mean!'. The teacher says she will play, but doesn't want to be mean. Kiara tells her she can't play with them if she's not going to be mean.

As made visible in this example, the sassy girl was discursively constructed as someone who was mean, and to be accepted as a sassy girl one had to display meanness. More importantly, meanness was not an 'emotional outburst' or moral response to a conflict with peers in the classroom or an effort to bully one particular child or children; nor was it associated with a child's lack of 'self regulation or lack of emotional intelligence. The girls recognized that the sassy girl was not prosocial. Indeed, being mean was the emotional theme of the sassy girl; it was the explicit and 
overarching rule of sassy girl play. Being a sassy girl, just as being a superhero, followed a specific storyline, and meanness was the feminine emotion that categorized them as 'sassy girls' as compared to other female categories located in the classroom discourse (e.g. nice girl, good girl, or bad girl).

Corsaro explains: 'Role play also allows kids to experiment with how different types of people in society act and how they relate to each another ... of great importance here for children are gender expectations about how girls and boys should act' (2005, p. 112). Rather than playing house with the emotional role of a loving and caring mother, or playing princess with the role of the female who falls in love with the prince, Kiara and Liza were playing the role of the aggressive female. Being sassy always included the performance of meanness (e.g. teasing, taunting, mocking, sticking out one's tongue, calling names, and physically hitting) that was directed towards someone outside of the core sassy girl group. It was a highly regulated and rule-oriented routine that drew upon a discourse of emotion that included both relational and physical aggression, and if one did not engage in these types of behaviors, they were not following the peer culture rules of the sassy girl routine.

Underwood describes relational aggression among girls as 'directed toward damaging another's self-esteem, social status, or both and may take such direct forms as verbal rejection, negative facial expression or body movements, or more indirect forms such as slanderous rumors or social exclusion' (2003, p. 189). The following videotaped exchange between myself and the sassy girl group (Liza, Kiara, Jackie, Mia, and Kim), during a play episode in the loft area, illustrates how the performance of these traits was purposefully embedded and appropriated in the girls' definition about what sassy girls 'do':

1 Researcher: Tell me about sassy girls.

2 Kiara: They be mean, and selfish, they hurt people. (laughs loudly)

3 Jackie: We knock people over.

4 Researcher: You knock people over?

5 Liza: And we're naughty people.

6 Researcher: You're naughty people?

7 Kiara: Ya ... we sneak up on people in their houses, and take all the people the people like the best away. (laughs)

8 All Girls: (laughing)

9 Jackie: And we put our houses ... right?!

10 Liza: And we put them in jail.

11 Researcher: You put them in jail?

12 Kiara: And my house is a beautiful yellow house ... with the flower room and pink stripes with dots in them!

13 Jackie: And you guys can't come to my house ... cuz it is so beautiful.

14 Kiara: And you can't come to her house. (turns and spits, sticking her tongue out at the

camera, again)

In line 2, Kiara states that sassy girls are mean, selfish and hurt people, followed by a loud mocking laugh. Next, Jackie states that they knock people over. In lines 5 and 7, Kiara and Liza continue by stating that sassy girls are 'naughty people' who 'sneak up on people and take the best away'. In this conversation, the females are constructing what it means to be a sassy girl, invoking a mocking or teasing type of laughter from all of the girls. In line 12, Kiara continues by stating that she has a beautiful yellow house. Jackie builds on this comment, stating in line 13 that others can't visit her house 'because it's so beautiful' using social exclusion and status aggression. Exclusion uses threats to the friendship or one's self-esteem, whereas status aggression is based on material culture and is used as a way to position the self as having more than another (e.g. I have the most beautiful house, clothes, hair, etc.). While status aggression does not threaten the loss of friendship explicitly, it does position the other as having and/or being something less than which places them in a 'deficit or subordinate position' (Madrid \& Kantor, 2009, p. 239). In this exchange, the girls were taking-up and trying-out positions of power through several forms of aggressive and deviant behavior: being selfish and naughty, hurting people, sneaking up on people, taking the best away from others, putting people in jail, and not letting them come to their beautiful house. 
The episode ends with Kiara using aggressive facial gestures by spitting and sticking out her tongue. The non-verbal facial gestures displayed show how the children embodied the role of being naughty and/or mean. Sticking out one's tongue and spitting communicates a message of disrespect and is considered rude within the Western culture and is another form of aggression used to harm or threaten a relationship (Lipkin, 2009). In the girls' peer culture, these non-verbal signs were similar to an adult's non-verbal gesture of 'the finger' to indicate a dislike or a nonverbal mode to 'flip off someone. These are communicative signs used in relationships with others to index a negative connotation and emotion of dislike, again drawing upon a discourse of meanness that was key to the performativity and (re)production of the sassy girl (Butler, 1999).

The sassy girl persona was not only overtly aggressive through verbal and non-verbal gestures, but was also covertly aggressive through tricking others, which is also a documented part of the 'mean girl' discourse (Peers, 2008). Below, in the videotaped episode, Kiara and Mia are playing sassy girl underneath the loft area when Luke enters into the play area:

22 Kiara: We're still sassy girls (looking in the mirror and fixing hair), and you don't even know that, silly.

23 Kiara: We'll make Luke eat poison. He will eat it and die. We will trick him.

$24 \mathrm{Mia}$ : He thinks shells are candy, yeah. But it's poison. It's poison and it will make you die if you eat it.

25 Kiara: I will have so much power.

26 Kiara: We don't like the princess at Disneyland anymore right? So we will become the real princesses, right, and live at Disneyland.

$27 \mathrm{Mia}$ : We will have our real names but be princesses.

28 Kiara: I will wear the most beautiful outfit ... We will have so much power we will destroy the earth!

29 Luke: I will be iron man

30 Kiara: I don't care, we have real power. Get away from our castle, we don't want you to play with us.

In the example above, Kiara, admiring herself in the mirror and fixing her blonde hair, tells Mia, 'We're still sassy girls, and you don't even know that, silly'. While she tells this to Mia, her statement is directed toward Luke. Silly Luke does not know they are sassy girls. They can make him eat poison and he will die. Within this script is the use of covert aggression and 'tricking' to harm someone. Tricking is a part of the popular culture image of the 'mean girl' who pretends to be nice to a peer, while sabotaging them behind the scenes. In this exchange, Kiara also places importance on her appearance by noting that she not only has so much power, but also will have 'the most beautiful outfit'. In the movie Mean Girls (2004), the so-called 'popular' nice girl tricks her peer into eating food that makes her fat, which is the ultimate revenge for a teenage girl (again highlighting the importance of appearance for females). Consistent with this line of thought, Peers (2008) notes that female aggression is often associated with verbal acts that 'sustain an outward appearance of the "lady-like" behavior expected of school girls' (Peers, 2008, p. 428). Kiara and Mia's actions toward Luke mimic the well-dressed powerful aggressive female who smiles politely while being covertly mean.

The two girls continue to take-up the mean girl or super girl discourse by stating that they will have so much power and will be the real princesses at Disneyland. This statement positions them as girls who can be anything they want, even a real princess at Disneyland with their real names. Through this position, they reject the notion that they must be anything other than who they are, while they continue to incorporate the false persona of niceness within the storyline with Luke, illustrating the contradictions and complexities associated with the mean girl or super girl subject position.

\section{Sassy Girl: resisting norms}

The sassy girl role, similar to boys' superhero play, reflected their concerns about having and using power - girl power - that was not located in female caring, nurturing, or domestication, but in meanness and aggression. Being mean, however, went directly against the school culture norms and rules about proper classroom behavior, especially with regard to physical aggression. For 
example, in the following event, Kiara and Kim were playing sassy girl on the playground. Prior to this interaction, they had been chasing boys, engaging in mock fighting, and teasing and hitting other male and female children. After being hit with a large plastic bat, Bill runs over to the teacher:

14 Teacher: Hey Kiara ... I hope you're not actually hitting people.

15 Kiara: (walks with her head down toward teacher)

16 Teacher: Kiara. Hey, (bends down to Kiara's eye level) you're not actually hitting people with

the bat, are you? Cuz you know I can't let you hit people with that, right?

17 Kiara: (shakes her head yes)

18 Kiara: (Walks over to the toy bin with the bat over her head. Throws the bat into the bin) I

don't want to go in our castle. Come on Kim Bear ... let's go. (walks away from the camera)

19 Kiara: (Walks quickly back to the camera, swinging hands aggressively at researcher) You

can't get it.

20 Researcher: Whoa...

21 Kiara: (Walks over to the edge of the sidewalk, hangs head, back turned to the camera)

AHHHH HAAAA (holding hands up on either side of face, curling fingers and wiggling them in a taunting manner).

22 (Kiara walks up to Mary and pulls her arm down forcefully).

Here, Kiara and Kim use the role to engage in physical aggression, which is stopped promptly by the teacher. Kiara responds by throwing the bat in the bin followed by 'mock' aggression where she swings her hand toward the researcher and then engages in non-verbal taunting by curling up her fingers and waving them mockingly. In line 22, Kiara forcefully, but covertly, pulls a younger peer's (i.e. Mary) arm down, out of the gaze of the teacher, which could be viewed as a type of resistance to the teacher's direct instructions that hitting was not allowed.

Relational aggression and physical violence rarely are viewed as useful or responsible behaviors for children, especially female children. Aapola et al contend that, 'It is still culturally more unacceptable for girls and women to express any type of aggression, particularly in public arenas, than for men' (2005, p. 119). The sassy girl role provided a venue of sorts in which the girls could break the school culture rule against being mean because they were just playing. The girls would argue (with teacher) that they were not mean because they were just playing mean girls. Kim would often state to the teacher: 'I am just being mean because Kiara told me to be a sassy girl'. The argument constructed by the girls could be viewed as a 'secondary adjustment' (Goffman, 1961) and resistance to the teachers and school rules about proper and normative behavior in the classroom. Goffman (1961) defines secondary adjustments as 'any habitual arrangements by which a member of an organization employs unauthorized means, or obtains unauthorized ends, or both, thus getting around the organization's assumptions as to what he should do and get and hence what he should be' (p. 198). Secondary adjustments are used by children to get around 'conventional rules like not bringing a personal item from home or moving certain toys from one play area to another' (Corsaro, 2005, p. 141).

The girls, however, were not using the peer culture routine to resist conventional classroom rules as noted by Corsaro (e.g. bringing a toy from home), but rather to get around the prevailing classroom social and moral norms about what children should do or play and the emotions they should display (i.e. care, love, and kindness). For example, in an interview the teacher noted her struggle with the sassy girl play because it contradicted her pedagogical philosophy about having caring relations in her classroom:

I think that it was definitely something that I constantly struggled with and I don't think I ever really felt like, 'Oh, okay, I'm handling this the right way'. I just feel like I'm constantly kind of walking that line of honoring the peer culture but yet not condoning certain behaviors by not doing anything. Because they do think - I mean I definitely wanted to honor their culture and not just be like coming in as the adult and you know, 'No you can't do that' but at the same time I also want to have a classroom of caring kids that take care of each other and caring relations among each other.

The sassy girl play was clearly not about these girls demonstrating they were caring kids that took care of each other, which made the teacher question and balance her own pedagogy with the rights 
of the children to play themes they felt were important in their peer culture (Madrid et al, 2013). As such, the play role provided access for the girls to resist the school rules and negotiate aggression without being labeled or positioned as a non-caring or aggressive girl by the teacher.

\section{Epilogue}

We changed the name of our club. It's not the sassy girl club anymore; it's the nice girls club now. (Kiara, January 2011)

Over time, the girls outwardly changed their stance about what was advantageous to play in the classroom. Kiara's statement, which occurred two months after the eight-week targeted observation of the play theme ended, illustrates that, at four-years-old, she was very much aware of the difference between being a sassy girl and a nice girl. Aapola et al (2005) suggest that 'Middle class forms of femininity tend to emphasize "being nice" at home, at school, and in friendships' (p. 117). Given that the sassy girls were not 'nice', tensions arose among their teachers, parents, and peers. The lead teacher indicated that the term 'sassy' had become a 'potty' (i.e. bad) word among the children in the preschool classroom. This shift in sassy as being a viable play theme for a select group of girls to a potty word appeared to coincide with marked issues of physical aggressiveness:

Teacher: Yeah, Kim strangled Kiara in front of Natalie and her parents, and it was a huge deal.

They had to debrief with me about the hostile environment that Natalie is in and took the whole weekend to talk to Natalie about the incident. They wanted me to suggest books they could read to Natalie about it, so Connie wants to write a social story, 'Hands are for hugging, not for strangling'. I talked to Connie today about Liza and we decided that I am going to start letting her peers kick her out if she is being too mean and violent. This way it's coming from them, not me, and it empowers them to tell her that she can't be mean and hurt people in our class. I'll let you know how it goes.

Here, the teacher notes how the theme became a concern for parents and peers who had witnessed and/or were targets of the physically aggressive acts. The actions and reactions of the sassy girl contradicted commonly held beliefs about how females should behave at school (i.e. hands are for hugging, not for strangling). That is, female 'Niceness means controlling ones emotions and first and foremost one's aggressive feelings, being sweet, friendly, and successful at school' (Aapola et al, 2005, p. 119). Thus, while there was not an explicit censorship and/or ban from the teacher to stop the sassy girl play theme, there was an explicit disapproval from the adult culture in general about how girls should play in the preschool classroom and notions about 'proper' schoolgirl behavior (Walkerdine, 1997). This shift in the girls' play name of their club, however, does not indicate the sassy girl disappeared, but rather she disappeared from the overt school culture.

\section{Conclusion}

During the time the play routine was constructed and became prominent in the classroom, the sassy girl play peer culture routine provided a play venue for Kiara and Liza to push the boundaries around aggression in the preschool classroom, giving them access to a subject position that traditionally would not be supported by the local school culture and the dominant Western culture in the USA. The play role further offered a play 'space' where the girls could explore being mean through a script that did not position them as naughty, but the play role as naughty. This 'secondary adjustment' allowed them to navigate multiple subjectivities (i.e. nice girl/mean girl), and resist social and moral discourses about proper female behavior, while also building alliances by acting not just as one individual sassy girl, but rather as a group of 'sassy girl(s)'.

The findings of this ethnographic study indicate that meanness appeared to be a viable, although contested, script for these young children to 'play' with their peers. Kiara and Liza, along with their core group of sassy girls, were taking-up a storyline associated with being female in the twenty-first century. There certainly was a 'sassy, don't-mess-with-me' attitude in Kiara and Liza's use of the play theme with their peers (Aapola et al, 2005, p. 28). It is no surprise that this subject position would be reflected in the play themes of young children as representations of femininity have undergone a transformation with the rise of the new super or mean girl discourse in popular 
culture (Taft, 2004; Ringrose, 2006). Children in Western societies are immersed with popular culture and media images of the neo-liberal, independently driven, powerful female (Harris, 2004). This image can be found within contemporary storylines such as Disney's Tangled (2011), Mattel's Barbie and the Three Musketeers (2009), and of course Mean Girls (2004). But being sassy in real life versus in the media was problematic for these two female children as seen in the teachers' and their peers' discomfort of the use of the play role and resultant social and physical aggression.

Developmental-psychological literature around girl's aggression often positions indirect aggression as a 'natural' or inherent aspect of femininity. Gonick (2004, p. 397) writes:

There is a suggestion that there is something inherent about girlhood and girls themselves which produce these behaviors, rather than seeing them as strategies for negotiating the particular time and place in which some girls are living. The effect is that not only are differences between girls and the particular circumstances of their lives glossed over, but girls' layered and complex expression of identity, power, and resistance are collapsed into certain ubiquitous meanings of girlhood with an ever expanding reach.

It is important to note that this study does not attempt to argue that preschool females are inherently socially and physically aggressive, or displaying pathological behavior through the play theme presented. Rather, the argument posed and the significance of the findings are that the sassy girl play theme was clearly a gendered play role that these particular female children saw as an option within the repertoire of feminine play roles afforded to them as females in a Western society - an option focused on females exploring meanness, which contradicts the commonly held assumption about female play roles as those centered on nurturing, caring, and passivity (Shields, 2002).

The finding also should not be interpreted to suggest that this theme is harmful or to alarm teachers that preschool females are now 'mean girls'. Rather, the findings should be examined with a lens that allows educators to understand the purposes of feminine play roles that use aggression. Educators must be critically aware of the contexts that these gendered roles are embedded within and what these roles might offer young female children, considering that young children are not just reproducing adult roles, but rather are appropriating them for their own peer culture purposes of gaining power and sharing control with peers. If teachers thwart such attempts to allow girls to perform girlhood on their own terms, a deeper understanding about the possible meanings and interpretations of twenty-first-century femininity might be overlooked, and limit various ways of 'doing' and 'un-doing' gender.

Educators must also reconsider censoring or banning such play roles as children will often take restricted play underground (Corsaro, 2003; Madrid, 2011) leaving little room for dialogue about gendered identities and aggression in the classroom. Awareness of the aggressive play themes in girls play provides an initial understanding about how feminist and post-feminist images and discourses are being appropriated by children through gendered ways of 'playing' the world around them. It would be of interest to explore female children's play themes not only in this one classroom in the USA, but also in other countries and classrooms to examine how emotional themes are being played out by young females globally in different cultures, and the implications of such themes for preschool children's social and emotional lives within and outside of the classroom.

\section{References}

Aapola, S., Gonick, M. \& Harris, A. (2005) Young Femininity: girlhood, power, and social change. New York: Palgrave Macmillan.

Barbie and the Three Musketeers (2009) Produced by R. Hudnut, Directed by W. Lau [Motion picture]. USA: Rainmaker Entertainment.

Blaise, M. (2005) Playing it Straight: uncovering gender discourses in the early childhood classroom. New York: Routledge.

Bloome, D., Power Carter, S., Morton Christian, S., Otto, S. \& Shurat-Farris (2005) Discourse Analysis and the Study of Classroom Language and Literacy Events. A Microethnographic Perspective. Mahwah, NJ: Lawrence Erlbaum.

Brooks, A. (1997) Postfeminisms: feminism, cultural theory, and cultural forms. New York: Routledge. 
Burr, V. (2003) Social Constructionism. New York: Routledge.

Butler, J. (1999) Gender Trouble: feminism and the subversion of identity. New York: RoutledgeFalmer.

Corsaro, W. (1985) Friendships and Peer Culture in the Early Years. Norwood, NJ: Ablex.

Corsaro, W. (2003) We're Friends Right? Washington, DC: Joseph Henry Press.

Corsaro, W. (2005) The Sociology of Childhood. Thousand Oaks, CA: Sage.

Davies, B. (1989) Frogs and Snails and Feminist Tales: preschool children and gender. Sydney: Allen \& Unwin.

Davies, B. \& Harré, R. (1990) Positioning: conversation and the production of selves, Journal for the Theory of Social Behavior, 20(1), 43-63. http: / /dx.doi.org/10.1111/j.1468-5914.1990.tb00174.x

Davies, B. (2000). A Body of Writing 1990-1999. New York: Alta Mira Press.

Emerson, R., Fretz, R. \& Shaw, L. (1995) Writing Ethnographic Field Notes. Chicago: University of Chicago Press. http: / / dx.doi.org/10.7208/ chicago/9780226206851.001.0001

Fernie, D., Davies, B., Kantor, R. \& McMurray, P. (1993) Learning to be a Person in the Preschool: creating integrated gender, school culture, and peer culture positioning, International Journal of Qualitative Studies in Education, 6(2), 95-110. http:/ / dx.doi.org/10.1080/0951839930060201

Fernie, D., Madrid, S. \& Kantor, R. (Eds) (2011) Educating Toddlers to Teachers: learning to see and influence the school and peer cultures of classrooms. Cresskill, NJ: Hampton Press.

Genz, S. (2009) Postfeminities in Popular Culture. New York: Palgrave Macmillan. http: / / dx.doi.org/10.1057/9780230234413

Gergen, K.J. (1999) An Invitation to Social Construction. Thousand Oaks, CA: Sage.

Gilbert, P. (1994) 'And They Lived Happily Ever After': cultural storylines and the construction of gender, in A.H. Dyson \& C. Genishi (Eds) The Need for Story: cultural diversity in classroom community. Urbana, IL: National Council of Teachers of English.

Goffman, E. (1961) Asylums: essays on the social situations on mental patients and other inmates. New York: Random House.

Gonick, M. (2004) The Mean Girl Crisis: problematizing representation of girls friendships, Feminism and Psychology, 14(3), 395-400. http: / dx.doi.org/10.1177/0959353504044641

Harris, A. (2004) Future Girl: young women in the twenty-first century. London: Routledge.

Hatch, J.A. (2002) Doing Qualitative Research in Education Settings. New York: State University of New York.

Kantor, R. \& Fernie, D. (2003) Becoming Ethnographers of an Early Childhood Classroom, in R. Kantor \& D. Fernie (Eds) Early Childhood Classroom Processes, pp. 1-20. Cresskill, NJ: Hampton Press.

Kyratzis, A. (2004) Talk and Interaction among Children and the Co-construction of Peer Culture Groups and Peer Culture, Annual Review Anthropology, 33, 625-649. http:/ / dx.doi.org/10.1146/annurev.anthro.33.070203.144008

Lipkin, E. (2009) Girl Studies. California: Seal Press.

Lutz, C. (1988) Unnatural Emotion: everyday sentiments on a micronesian atoll and their challenge to a western theory. Chicago: University of Chicago Press.

MacNaughton, G. (2000) Rethinking Gender in Early Childhood Education. London: Paul Chapman.

Madrid, S. (2011) Romantic Love among Peers in the Preschool Classroom, in D. Fernie, S. Madrid \& R. Kantor (Eds) Educating Toddlers to Teachers: learning to see and influence the School and Peer Cultures of Classrooms. Cresskill, NJ: Hampton Press. http: / dx.doi.org/10.1177/1476718X13484240

Madrid, S., Baldwin, N. \& Frye, E. (2013) 'Professional Feeling': one early childhood educator's discomfort as a teacher and learner, Journal of Early Childhood Research. http: / / dx.doi.org/ 10.1177/ 1476718X13484240

Madrid, S. \& Kantor, R. (2009) Being Kitties in a Preschool Classroom: group harmony and acting proper in a female peer culture play routine, Ethnography and Education, 4(2), 229-247. http: / / dx.doi.org/ 10.1080/17457820902972903

Mandell, N. (1988) The Least-Adult Role in Studying Children, Journal of Contemporary Ethnography, 16, 433-467. http: / / dx.doi.org/10.1177/0891241688164002

Mean Girls (2004) Produced by J. Powers, Directed by M. Waters [Motion picture]. USA: Paramount Pictures.

Peers, J. (2008) Meanness, in C. Mitchell \& J. Reid-Walsh (Eds) Girl Culture: an encyclopedia. Westport, CT: Greenwood.

Ringrose, J. (2006) A New Universal Mean Girl: examining the discursive construction and social regulation of a new feminine pathology, Feminism and Psychology, 16(4), 405-424.

http: / / dx.doi.org/10.1177/0959353506068747 
Ringrose, J. \& Walkerdine, V. (2008) What Does it Mean to be a Girl in the Twenty-first Century? Exploring Some Contemporary Dilemmas of Femininity and Girlhood in the West, in C. Mitchell \& J. Reid-Walsh (Eds) Girl Culture: an encyclopedia. Westport, CT: Greenwood.

Shields, S. (2002) Speaking from the Heart: gender and the social meaning of emotion. Cambridge, MA: Cambridge University Press.

Spradley, J. (1980) Participant Observation. California: Wadsworth Thomson.

Taft, J. (2004) Girl Power Politics: pop culture barriers and organizational resistance, in A. Harris (Ed.) All about the Girl: culture, power, \& identity. London: Routledge.

Tangled (2011) Produced by R. Conli, Directed by N. Greno \& B. Howard [Motion picture]. USA: Walt Disney Studios Home Entertainment.

Thorne, B. (1993) Gender Play: girls and boys in schools. New Brunswick, NJ: Rutgers University.

Underwood, M. (2003) Social Aggression among Girls. New York: Guilford Press.

Walkerdine, V. (1997) Schoolgirl Fictions. London: Verso.

Weedon, C. (1997) Feminist Practices and Poststructural Theory. Oxford: Blackwell.

Wohlwend, K. (2009) Damsels in Discourse: girls consuming and producing identity texts through Disney princess play, Reading Research Quarterly, 44(1) 57-83. http:/ / dx.doi.org/10.1598/RRQ.44.1.3

Yelland, N. \& Grieshaber, S. (1998) Blurring the Edges, in N. Yelland (Ed.) Gender in Early Childhood. London: Routledge.

SAMARA MADRID is an Assistant Professor in the Elementary and Early Education Department at the University of Wyoming. She teaches undergraduate and graduate courses in early childhood education and qualitative methodology. Her research has focused on the ethnographic study of early childhood classrooms, with an emphasis on exploring the emotional lives of teachers and children using peer culture, feminist and post-structuralist perspectives. Correspondence: smadrid3@uwyo.edu 